\title{
Assessment of Undiscovered Oil and Gas Resources in the Mancos- Menefee Composite and Underlying Todilto Total Petroleum Systems of the San Juan Basin Province, New Mexico and Colorado, 2020
}

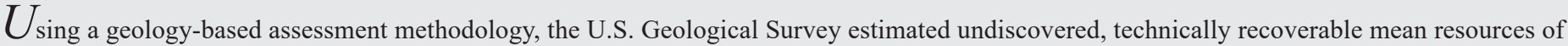
12 million barrels of oil and 27 trillion cubic feet of gas in the Mancos-Menefee Composite and underlying Todilto Total Petroleum Systems of the San Juan Basin Province, New Mexico and Colorado.

\section{Introduction}

The U.S. Geological Survey (USGS) completed a geologybased assessment of undiscovered, technically recoverable conventional and continuous, or unconventional, oil and gas resources in the Mancos-Menefee Composite Total Petroleum System (TPS) and underlying Todilto TPS (figs. 1-3). Reservoir

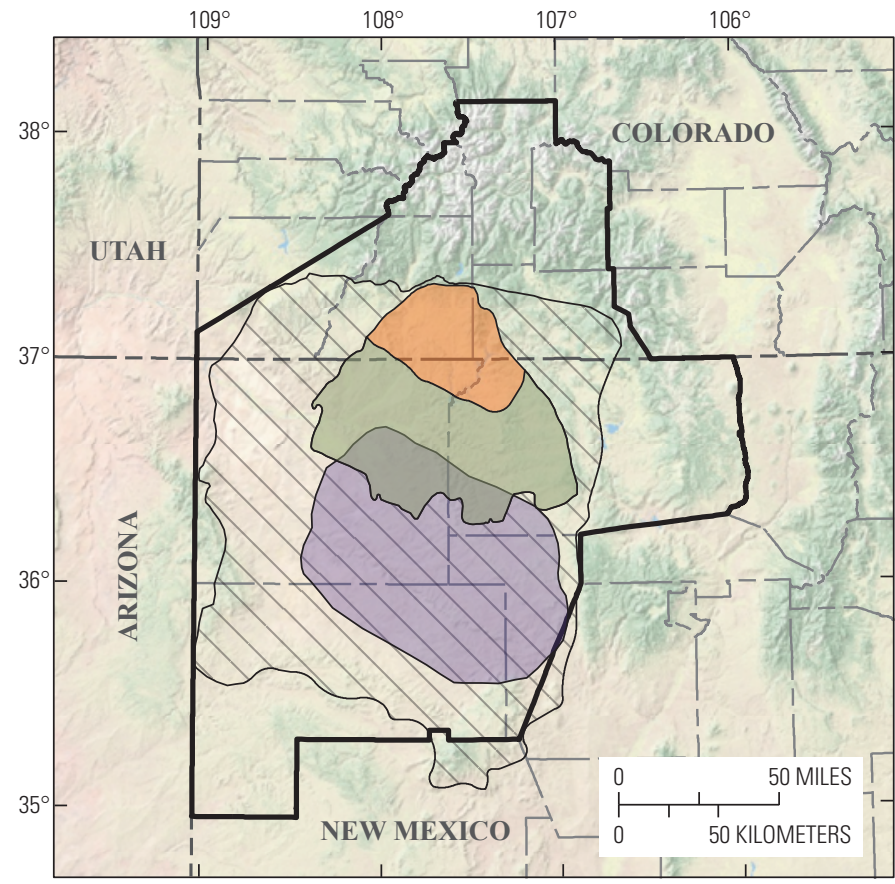

Base map from U.S. Department of the Interior, National Park Service

\section{EXPLANATION}

Entrada Sandstone Conventional Oil AU

Dakota-Lower Mancos Conventional Oil and Gas AU

Northeastern Dakota-Lower

Mancos Continuous Gas AU

Southwestern Dakota-Lower

Mancos Continuous Gas AU

San Juan Province Basin boundary

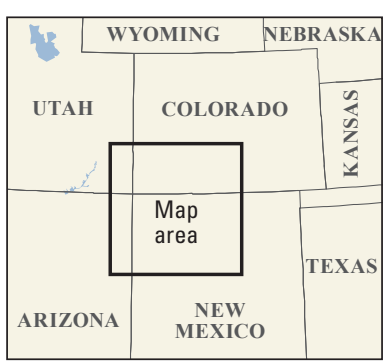

Figure 1. Map showing the San Juan Basin Province in New Mexico and Colorado and the extents of the Entrada Sandstone Conventional Assessment Unit (AU), Dakota-Lower Mancos Conventional Oil and Gas AU, Northeastern Dakota-Lower Mancos Continuous Gas AU, and Southwestern Dakota-Lower Mancos Continuous Gas AU. rocks in the Mancos-Menefee TPS include (1) Dakota Sandstone, (2) Gallup Sandstone, (3) Mancos Shale and associated sandstones of the Tocito Sandstone Lentil and El Vado Sandstone Member, and (4) Mesaverde Group. These units have primarily produced oil and gas from vertical drilling, where commingling of productive intervals is common. In recent years, horizontal drilling has been utilized, particularly in the Mancos Shale (IHS Markit $^{\circledR}$, 2019). The Todilto TPS consists of the Jurassic

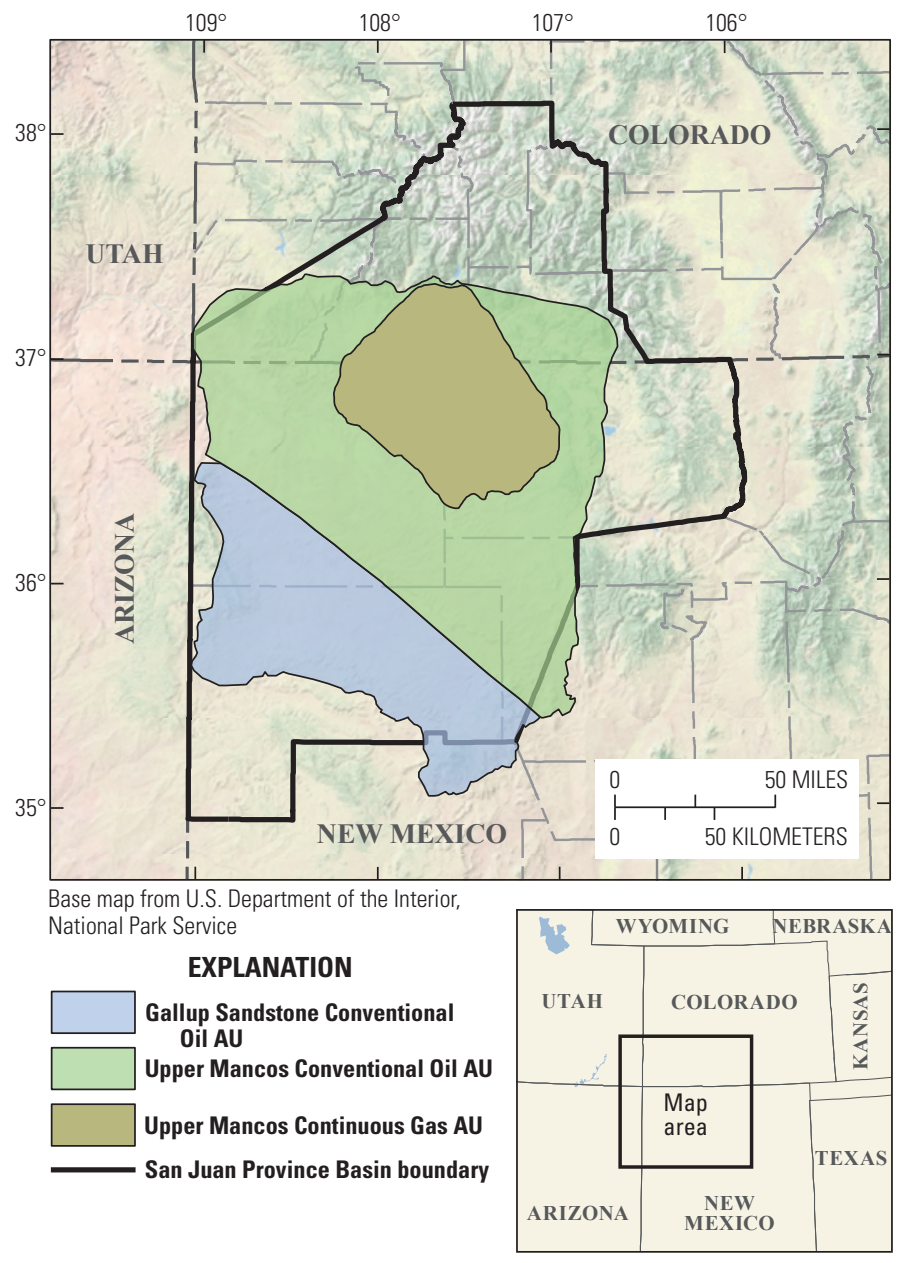

Figure 2. Map showing the San Juan Basin Province in New Mexico and Colorado and the extents of the Gallup Sandstone Conventional Oil Assessment Unit (AU), Upper Mancos Conventional Oil AU, and Upper Mancos Continuous Gas AU. 
Table 1. Key input data for four conventional and six continuous assessment units (AUs) in the San Juan Basin Province, New Mexico and Colorado.

[Well drainage area, success ratio, and estimated ultimate recovery are defined partly using U.S. analogs. The average EUR input is the minimum, median, maximum, and calculated mean. Gray shading indicates not applicable. AU, assessment unit; \%, percent; EUR, estimated ultimate recovery (per well); MMBO, million barrels of oil;

$\mathrm{BCFG}$, billion cubic feet of gas]

\begin{tabular}{|c|c|c|c|c|c|c|c|c|}
\hline \multirow{2}{*}{$\begin{array}{l}\text { Assessment input data- } \\
\text { Conventional AUs }\end{array}$} & \multicolumn{4}{|c|}{ Entrada Sandstone Conventional Oil AU } & \multicolumn{4}{|c|}{$\begin{array}{c}\text { Dakota-Lower Mancos Conventional } \\
\text { Oil and Gas AU }\end{array}$} \\
\hline & Minimum & Median & Maximum & $\begin{array}{l}\text { Calculated } \\
\text { mean }\end{array}$ & Minimum & Median & Maximum & $\begin{array}{l}\text { Calculated } \\
\text { mean }\end{array}$ \\
\hline Number of oil fields & 1 & 2 & 3 & 2 & 1 & 2 & 4 & 2.1 \\
\hline Size of oil fields (MMBO, oil) & 0.5 & 1 & 4 & 1.1 & 0.5 & 1 & 6 & 1.2 \\
\hline Number of gas fields & & & & & 1 & 2 & 3 & 2.0 \\
\hline Size of gas fields (BCFG, gas) & & & & & 3 & 6 & 25 & 6.7 \\
\hline AU probability & 0.7 & & & & 0.8 & & & \\
\hline \multirow[b]{2}{*}{$\begin{array}{l}\text { Assessment input data- } \\
\text { Conventional AUs }\end{array}$} & \multicolumn{4}{|c|}{ Gallup Sandstone Conventional Oil AU } & \multicolumn{4}{|c|}{ Upper Mancos Conventional Oil AU } \\
\hline & Minimum & Median & Maximum & $\begin{array}{l}\text { Calculated } \\
\text { mean }\end{array}$ & Minimum & Median & Maximum & $\begin{array}{l}\text { Calculated } \\
\text { mean }\end{array}$ \\
\hline Number of oil fields & 1 & 2 & 3 & 2 & 1 & 3 & 5 & 3.0 \\
\hline Size of oil fields (MMBO, oil) & 0.5 & 1 & 4 & 1.1 & 0.5 & 2 & 5 & 2.1 \\
\hline AU probability & 0.7 & & & & 1.0 & & & \\
\hline \multirow{2}{*}{$\begin{array}{l}\text { Assessment input data- } \\
\text { Continuous AUs }\end{array}$} & \multicolumn{4}{|c|}{$\begin{array}{c}\text { Northeastern Dakota-Lower Mancos } \\
\text { Continuous Gas AU }\end{array}$} & \multicolumn{4}{|c|}{$\begin{array}{c}\text { Southwestern Dakota-Lower Mancos } \\
\text { Continuous Gas AU }\end{array}$} \\
\hline & Minimum & Mode & Maximum & $\begin{array}{l}\text { Calculated } \\
\text { mean }\end{array}$ & Minimum & Mode & Maximum & $\begin{array}{l}\text { Calculated } \\
\text { mean }\end{array}$ \\
\hline $\begin{array}{l}\text { Potential production area of AU } \\
\text { (acres) }\end{array}$ & 100,000 & 400,000 & 730,000 & 410,000 & 500,000 & $1,000,000$ & $1,784,000$ & $1,094,667$ \\
\hline $\begin{array}{l}\text { Average drainage area of wells } \\
\text { (acres) }\end{array}$ & 40 & 80 & 120 & 80 & 40 & 80 & 120 & 80 \\
\hline Area untested in AU (\%) & 70 & 85 & 95 & 83.3 & 55 & 70 & 85 & 70 \\
\hline Success ratio $(\%)$ & 70 & 80 & 90 & 80 & 70 & 80 & 90 & 80 \\
\hline Average EUR (BCFG, gas) & 0.8 & 1 & 2 & 1.06 & 0.8 & 1.2 & 2 & 1.24 \\
\hline AU probability & 1.0 & & & & 1.0 & & & \\
\hline \multirow{2}{*}{$\begin{array}{l}\text { Assessment input data- } \\
\text { Continuous and Coalbed AUs }\end{array}$} & \multicolumn{4}{|c|}{ Upper Mancos Continuous Gas AU } & \multicolumn{4}{|c|}{ Menefee Coalbed Gas AU } \\
\hline & Minimum & Mode & Maximum & $\begin{array}{l}\text { Calculated } \\
\text { mean }\end{array}$ & Minimum & Mode & Maximum & $\begin{array}{l}\text { Calculated } \\
\text { mean }\end{array}$ \\
\hline $\begin{array}{l}\text { Potential production area of AU } \\
\text { (acres) }\end{array}$ & 1,000 & 500,000 & $1,942,300$ & 814,433 & 1,000 & $1,000,000$ & $5,291,000$ & $2,097,333$ \\
\hline $\begin{array}{l}\text { Average drainage area of wells } \\
\text { (acres) }\end{array}$ & 100 & 160 & 240 & 166.7 & 60 & 80 & 160 & 100 \\
\hline Area untested in $\mathrm{AU}(\%)$ & 90 & 95 & 98 & 94.3 & 100 & 100 & 100 & 100 \\
\hline Success ratio $(\%)$ & 70 & 80 & 90 & 80 & 10 & 50 & 90 & 50 \\
\hline Average EUR (BCFG, gas) & 0.1 & 0.6 & 3 & 0.73 & 0.02 & 0.08 & 0.25 & 0.09 \\
\hline AU probability & 1.0 & & & & 0.9 & & & \\
\hline \multirow{2}{*}{$\begin{array}{l}\text { Assessment input data- } \\
\text { Continuous AUs }\end{array}$} & \multicolumn{4}{|c|}{ Northeastern Mesaverde Continuous Gas AU } & \multicolumn{4}{|c|}{ Southwestern Mesaverde Continuous Gas AU } \\
\hline & Minimum & Mode & Maximum & $\begin{array}{l}\text { Calculated } \\
\text { mean }\end{array}$ & Minimum & Mode & Maximum & $\begin{array}{l}\text { Calculated } \\
\text { mean }\end{array}$ \\
\hline $\begin{array}{l}\text { Potential production area of AU } \\
\text { (acres) }\end{array}$ & 50,000 & 400,000 & 749,000 & 399,667 & 200,000 & 700,000 & $1,236,200$ & 712,067 \\
\hline $\begin{array}{l}\text { Average drainage area of wells } \\
\text { (acres) }\end{array}$ & 40 & 80 & 120 & 80 & 40 & 80 & 120 & 80 \\
\hline Area untested in $\mathrm{AU}(\%)$ & 65 & 78 & 90 & 77.7 & 30 & 50 & 75 & 51.7 \\
\hline Success ratio $(\%)$ & 50 & 70 & 90 & 70 & 70 & 80 & 90 & 80 \\
\hline Average EUR (BCFG, gas) & 0.8 & 1 & 2 & 1.06 & 1.6 & 1.8 & 2.5 & 1.84 \\
\hline AU probability & 1.0 & & & & 1.0 & & & \\
\hline
\end{tabular}


Todilto Limestone Member of the Wanakah Formation and the underlying Entrada Sandstone. The Mancos-Menefee Composite TPS and Todilto TPS were last assessed by the USGS in 2002 , as part of a broad assessment of oil and gas resources within the Jurassic and Cretaceous reservoirs of the San Juan Basin (Ridgley and Hatch, 2013; Ridgley and others, 2013).

\section{Geologic Summary}

In the Todilto TPS, the Middle Jurassic Todilto Limestone Member hosts organic-rich limestone beds, deposited in a marine-lacustrine system, that are thermally mature in some regions of the San Juan Basin. The Entrada Sandstone is an extensive eolian sandstone deposit with dune topography. Minor downward migration of oil from the Todilto into dune crests of the underlying Entrada formed localized conventional oil accumulations (Ridgley and Hatch, 2013).

Within the overlying Mancos-Menefee Composite TPS, Cretaceous reservoir strata range from the base of the Dakota Sandstone to the lowermost part of the Cliff House Sandstone of the Mesaverde Group. Rock units of the Mancos-Menefee Composite TPS were deposited during transgressive and regressive episodes along the Cretaceous Western Interior
Seaway. The Mancos Shale is a primary source of oil and gas resources in the San Juan Basin and consists of marine shale (with Type II organic matter), siltstone, and fine-grained sandstones. The Mancos Shale is more than 2,000 feet thick in some areas of the basin. In the upper part of the Mancos Shale, shoreface sandstones of the Tocito Sandstone Lentil and El Vado Sandstone Member form significant oil and gas reservoirs. The overlying Menefee Formation of the Mesaverde Group consists of fluvial channel sandstones, as well as carbonaceous shale and coal beds, which may also have generated hydrocarbons. Both the Mancos Shale and Menefee Formation were sufficiently buried to generate oil and gas from the Eocene to the Miocene. Hydrocarbons from the Mancos Shale, with possible contributions from the Menefee Formation, migrated into adjacent reservoir rocks to form the Mancos-Menefee Composite TPS (Ridgley and others, 2013; Broadhead, 2015).

\section{Assessment Units}

One conventional assessment unit (AU), the Entrada Sandstone Conventional Oil AU, was defined for the Todilto TPS (fig. 1).

Table 2. Results for five conventional and six continuous assessment units (AUs) in the San Juan Basin Province, New Mexico and Colorado.

[Results shown are fully risked estimates. F95 represents a 95-percent chance of at least the amount tabulated; other fractiles are defined similarly. Gray shading indicates not applicable. MMBO, million barrels of oil; BCFG, billion cubic feet of gas; NGL, natural gas liquids; MMBNGL, million barrels of natural gas liquids; CBG, coal bed gas]

\begin{tabular}{|c|c|c|c|c|c|c|c|c|c|c|c|c|c|c|}
\hline \multirow{3}{*}{$\begin{array}{l}\text { Total petroleum systems and } \\
\text { assessment units (AUs) }\end{array}$} & \multirow{3}{*}{$\begin{array}{c}\text { AU } \\
\text { prob- } \\
\text { ability }\end{array}$} & \multirow{3}{*}{$\begin{array}{c}\text { Accum- } \\
\text { ulation } \\
\text { type }\end{array}$} & \multicolumn{12}{|c|}{ Total undiscovered resources } \\
\hline & & & \multicolumn{4}{|c|}{ Oil (MMBO) } & \multicolumn{4}{|c|}{ Gas (BCFG) } & \multicolumn{4}{|c|}{ NGL (MMBNGL) } \\
\hline & & & F95 & F50 & F5 & Mean & F95 & F50 & F5 & Mean & F95 & F50 & F5 & Mean \\
\hline \multicolumn{15}{|c|}{ Todilto Total Petroleum System } \\
\hline $\begin{array}{l}\text { Entrada Sandstone Conventional } \\
\text { Oil AU }\end{array}$ & 0.7 & Oil & 0 & 2 & 3 & 2 & 0 & 2 & 3 & 2 & 0 & 0 & 0 & 0 \\
\hline \multicolumn{15}{|c|}{ Mancos-Menefee Composite Total Petroleum System } \\
\hline \multirow{2}{*}{$\begin{array}{l}\text { Dakota-Lower Mancos } \\
\text { Conventional Oil and Gas AU }\end{array}$} & \multirow{2}{*}{0.8} & Oil & 0 & 2 & 4 & 2 & 0 & 3 & 6 & 3 & 0 & 0 & 0 & 0 \\
\hline & & Gas & & & & & 0 & 12 & 20 & 11 & 0 & 0 & 1 & 0 \\
\hline $\begin{array}{l}\text { Gallup Sandstone Conventional } \\
\text { Oil AU }\end{array}$ & 0.7 & Oil & 0 & 2 & 3 & 2 & 0 & 0 & 1 & 0 & 0 & 0 & 0 & 0 \\
\hline $\begin{array}{l}\text { Upper Mancos Conventional Oil } \\
\text { AU }\end{array}$ & 1.0 & Oil & 4 & 6 & 9 & 6 & 22 & 34 & 49 & 35 & 0 & 1 & 1 & 1 \\
\hline $\begin{array}{l}\text { Mesaverde Updip Conventional } \\
\text { Oil AU }\end{array}$ & & Oil & \multicolumn{12}{|c|}{ Not quantitatively assessed } \\
\hline $\begin{array}{l}\text { Total undiscovered conventional } \\
\text { resources }\end{array}$ & & & 4 & 12 & 19 & 12 & 22 & 51 & 79 & 51 & 0 & 1 & 2 & 1 \\
\hline \multicolumn{15}{|c|}{ Mancos-Menefee Composite Total Petroleum System } \\
\hline $\begin{array}{l}\text { Northeastern Dakota-Lower } \\
\text { Mancos Continuous Gas AU }\end{array}$ & 1.0 & Gas & & & & & 1,617 & 3,555 & 6,362 & 3,716 & 1 & 2 & 4 & 2 \\
\hline $\begin{array}{l}\text { Southwestern Dakota-Lower } \\
\text { Mancos Gas AU }\end{array}$ & 1.0 & Gas & & & & & 5,289 & 9,302 & 15,810 & 9,759 & 35 & 65 & 114 & 68 \\
\hline Upper Mancos Continuous Gas AU & 1.0 & Gas & & & & & 480 & 2,033 & 6,963 & 2,649 & 8 & 33 & 112 & 42 \\
\hline Menefee Coalbed Gas AU & 0.9 & CBG & & & & & 0 & 647 & 2,307 & 836 & 0 & 0 & 0 & 0 \\
\hline $\begin{array}{l}\text { Northeastern Mesaverde } \\
\text { Continuous Gas AU }\end{array}$ & 1.0 & Gas & & & & & 1,064 & 2,789 & 5,316 & 2,940 & 0 & 1 & 3 & 1 \\
\hline $\begin{array}{l}\text { Southwestern Mesaverde } \\
\text { Continuous Gas AU }\end{array}$ & 1.0 & Gas & & & & & 3,067 & 6,597 & 12,362 & 7,009 & 12 & 26 & 50 & 28 \\
\hline $\begin{array}{l}\text { Total undiscovered continuous } \\
\text { resources }\end{array}$ & & & & & & & 11,517 & 24,923 & 49,120 & 26,909 & 56 & 127 & 283 & 141 \\
\hline Total undiscovered resources & & & 4 & 12 & 19 & 12 & 11,539 & 24,974 & 49,199 & 26,960 & 56 & 128 & 285 & 142 \\
\hline
\end{tabular}


A total of four conventional AUs were delineated for the Mancos-Menefee Composite TPS (figs. 1-3): (1) Dakota-Lower Mancos Conventional Oil and Gas AU, (2) Gallup Sandstone Conventional Oil AU, (3) Upper Mancos Conventional Oil AU, and (4) Mesaverde Updip Conventional Oil AU.

In addition, six continuous AUs were defined for the Mancos-Menefee Composite TPS (figs. 1-3): (1) Northeastern Dakota-Lower Mancos Continuous Gas AU, (2) Southwestern Dakota-Lower Mancos Continuous Gas AU, (3) Upper Mancos Continuous Gas AU, (4) Menefee Coalbed Gas AU, (5) Northeastern Mesaverde Continuous Gas AU, and (6) Southwestern Mesaverde Continuous Gas AU.

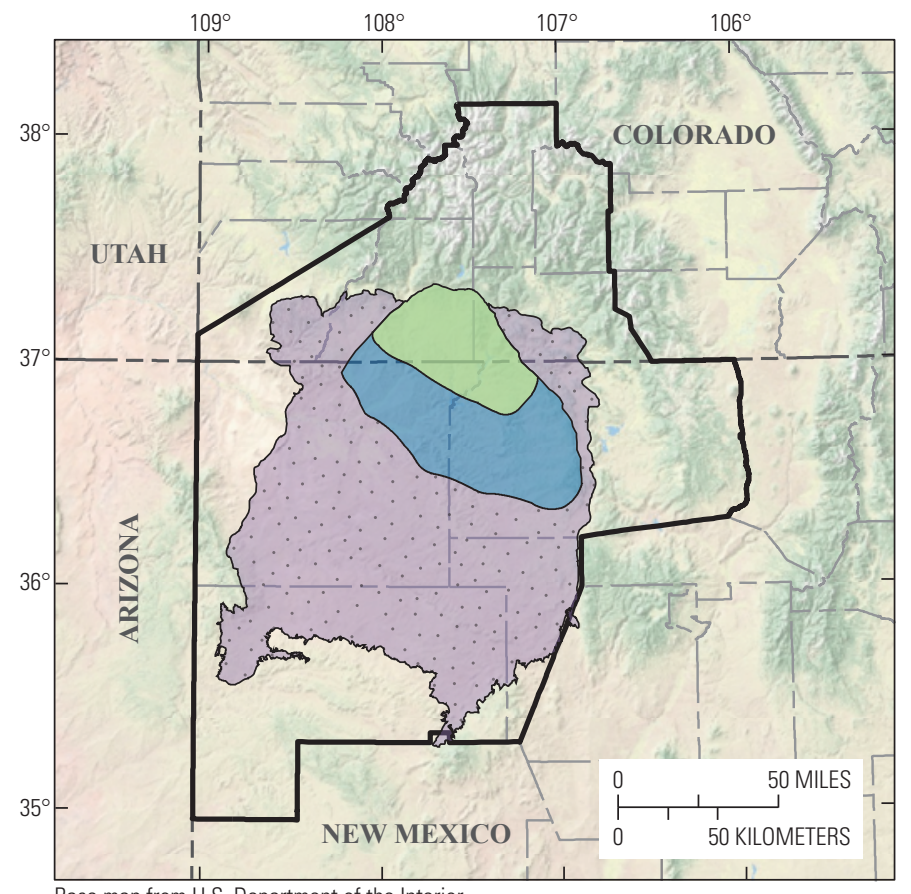

Base map from U.S. Department of the Interior, National Park Service
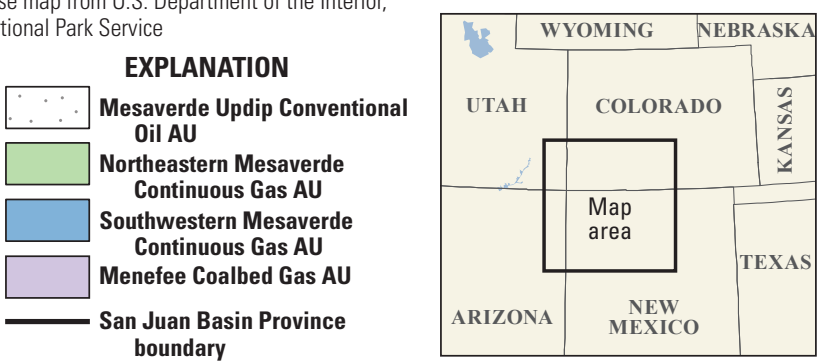

Figure 3. Map showing the San Juan Basin Province in New Mexico and Colorado and the extents of the Mesaverde Updip Conventional Oil Assessment Unit (AU; not assessed), Northeastern Mesaverde Continuous Gas AU, Southwestern Mesaverde Continuous Gas AU, and Menefee Coalbed Gas AU.
Assessment unit boundaries were primarily defined based on the regional extent of formations in the San Juan Basin and differences in gas to oil ratios. Key input data used to assess the Todilto and Mancos-Menefee Composite TPSs are listed in table 1 .

\section{Undiscovered Resources Summary}

The USGS assessed undiscovered, technically recoverable continuous and conventional oil and gas resources for $1 \mathrm{AU}$ in the Todilto TPS and 10 AUs in the Mancos-Menefee TPS; the Mesaverde Updip Conventional Oil AU was not quantitatively assessed (table 2). Total estimated mean resources are 12 million barrels of oil (MMBO) with an F95-F5 range from 4 to $19 \mathrm{MMBO} ; 26,960$ billion cubic feet of gas (BCFG), or 27 trillion cubic feet of gas, with an F95-F5 range from 11,539 to $49,199 \mathrm{BCFG}$; and 142 million barrels of natural gas liquids (MMBNGL) with an F95-F5 range from 56 to 285 MMBNGL.

\section{References Cited}

Broadhead, R.F., 2015, The Upper Mancos Shale in the San Juan Basin-Three plays, conventional and unconventional: American Association of Petroleum Geologists, Search and Discovery Article No. 10791, 39 p., accessed February 2018 at http://www.searchanddiscovery.com/ documents/2015/10791broadhead/ndx_broadhead.pdf.

IHS Markit $^{\circledR}, 2019$, Enerdeq ${ }^{\mathrm{TM}}$ US well history and production database: Englewood, Colo., IHS Markit, accessed December 2019 at http://www.ihsmarkit.com. [Available from IHS Markit, 15 Inverness Way East, Englewood, CO 80112.]

Ridgley, J.L., Condon, S.M., and Hatch, J.R., 2013, Geology and oil and gas assessment of the Mancos-Menefee Composite Total Petroleum System, chap. 4 of U.S. Geological Survey San Juan Basin Assessment Team, comps., Total petroleum systems and geologic assessment of undiscovered oil and gas resources in the San Juan Basin Province, exclusive of Paleozoic rocks, New Mexico and Colorado: U.S. Geological Survey Digital Data Series 69-F, p. 1-97.

Ridgley, J.L., and Hatch, J.R., 2013, Geology and oil and gas assessment of the Todilto Total Petroleum System, San Juan Basin Province, New Mexico and Colorado, chap. 3 of U.S. Geological Survey San Juan Basin Assessment Team, comps., Total petroleum systems and geologic assessment of undiscovered oil and gas resources in the San Juan Basin Province, exclusive of Paleozoic rocks, New Mexico and Colorado: U.S. Geological Survey Digital Data Series 69-F, p. 1-29.

\section{For More Information}

Assessment and methodology information can also be accessed at the USGS Energy Resources Program website at https://energy.usgs.gov.

\section{Mancos-Menefee Composite and Todilto Total Petroleum Systems Assessment Team}

Kristen R. Marra, Christopher J. Schenk, Tracey J. Mercier, Heidi M. Leathers-Miller, Marilyn E. Tennyson, Thomas M. Finn, Cheryl A. Woodall, Michael E. Brownfield, Phuong A. Le, and Ronald M. Drake II 